\title{
職業教育の構造
}

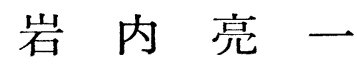

\section{1 社会機能としての職業教育}

職業教育を「職業遂行能力の向上を中心とした，制度化された職業的社会化」と規 定すると, その範囲・種類・機関法, 非常に広汎にわたる。職業指導, 職業教育の内 容, 職業こ関する学校教育制度, 職業教育諸機関の対社会的機能なぞ, 関連する事項 を列挙すれば数多くのテーマがあがってくる(1)。これらを個々の具体的な職業教育 の実際に関するものと, 社会機能の一部としての職業教育の役割に大別して考元るこ とができる。前者は職業教育の内的事項であり相対的にミクロな分野に属する。それ に対して後者法, 職業教育の外的事項であり, よりマクロな視野から考察される。

後者注社会の工業化との関連で扱われがちである。それは，ほとえどの工業化社会 が職業教育制度をもち，この制度が工業化に対して一定の役割を担ってきた，もしく は現に担うよう期待されているからである。また, 開発志向型の社会では, 職業教育 制度の整備酒高い関心がみられる。そのためわれわれは,ともすれば,職業教育制度が 工業化過程で, 社会からの要請のもとで発達し, 現段階では社会諸制度のなかに強固 にビルト・インされているという前提で, 論議を展開し実態を分析する傾向にある。 たとえば洋の東西を問わず, 大学工学部注, 高級技術者の盖成を通して社会の工業化 に寄与すると考えられることが多い。

ところがこのような通常の見解は, ある特定の時期の日本の職業教育の部分的現象 についての経験的認識にたっているに過ぎない。社会の工業化の諸段階において，ま た職業教育の制度化の諸形態によって, 両者の結びつきは非常に多様である。また職 業教育のあり方は, 工業化の特質によってのみ規定されるのではない。文化構造, 社 会構造, さらには歴史的経緯が，その結びつきに強く影響する。

現代の職業教育を評価するにあたって, これらマクロな諸関連を整理し, “職業教 育の構造” の枠組を構筑することが必要である。本稿㹥として, 主本の職業教育を

明治大学 
対象とするが，国際比較のための視点を準備する試みでもある。ここでは以下の四つ の諭点が準備される。それらは，(1)職業教育の制度化と工業化の関連，(2)工業化社会 の社会変動の過程における, 職業教育の専門化と社会的インパクト，(3)職業教育の段 階と社会階層との関係，(4)周辺的な職業教育の比重の增大である。

\section{2 工業化と職業教育の制度化}

まず，社会の工業化に対応して職業教育が制度化されるとする前提こそ検榇されな ければならない。制度的学校教育が工業化を導く重要な要因であると仮定する立場 を “教青先導論”（2）と命名すると，そのアナロジーとして “職業教育先尊論” とで も呼ぶべき仮設を措定することができる。職業教育がよりプラクティカルな侧面をも ち，立近代社会からの転換に直接的な効果をもたらす産業発達に然与古る手段とな り，離陸を経た後の経済成長の要因ともなる，一このように考えるの心゙一般的な通 念で琼る。「職業教育の制度化が産業発達に役立つ」(3) とする命題を再検討するのが 本節の放らいである。これはまた，“職業教育先導論”の見值しにもつらなる。

職業教育と産業発達の関係は, 少なくとも四つのタイプに分けられる。図 1 がそれ

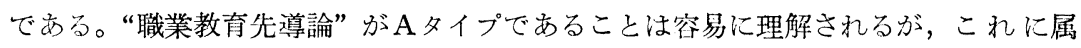
する典型例を見出与のは容易ではない。しかしこの “職業教育先導淪”に合致する例

A

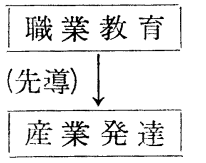

B

\begin{tabular}{ll|}
\hline 産業発澾| & 職業教育 \\
(先導) & (先行) $入$ \\
\hline 職業教育 & 珄業発達 \\
\hline
\end{tabular}

D

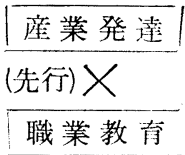

図 1 職業教育と産業発達の関連

は開発途上国の政策意図にみられる。開発をめざすこれらの国のいくつかが，職業教 育の充実夌優先するのは，それによって経済的停洲からの脱却灾図るからである。

明治期の技術教育はどうか。しばしば引用される東京職工学校の設立趣意書は，あ たかもこの学校が工業化を先導する役割を果たしたかの印象を与える。ところがこの 趣意書は，当事者の期待をあらわすものであり，その後の経過は，学校の設立意図を十 分に満たさなかった。日本の技術教育史のうち, 職業教育が産業定率引した例として, 工部大学校をあげるのが妥当である。これは導入技術の操作，科学・技術の内在化， 日本人による傭外人技術者の代置を目的として設置された教育機関である。実習の 場が工部省管轄の工場鉱山であり，学生は卒業後もこれら現場の技術開発に従事する ことを義務づけられた。その意味で，この教育機関が，日本の初期工業化と平行し， 技術尊入空側面的に助成する機能を果たしたといえよう(4)。工部大学校の卒業生の 一人注，大学・政府・企業と職場を変えながら，機械・電父・電力の諸事業の創始に 指導的な貢献をなした。これは個人が産業発達を先導した败例である(5)。 
図 1 の B は，産業の成熟が職業教育制度に刺激を与える形態に代表される。ここで は産業の据大が人材の需要を喚起する。「国民所得倍増計画」の具体的計画を策定し た「教育訓練小委員会報告」，高等専門学校の設置およびその前段階の専科大学法案 などはどれも，持続的な経済成長に備えての工業人材の量的および質的払充を意図す るものであった。これらに先立つ1956 年, 日経連に「技術教育委員会」が設置され た。その翌年発表された「漱時代の要請に対応する技術教育に関する意見」は，理工 科大学の改善についての提案であるが, 産業の進展に適応すべく高等教育体系の改変 を要求している。座業界が職業教育制度に影響を与えたのである(6)。

制度的な職業教育と産業発達が，それぞれ独立的に作動するのが，C，Dのタイプ である。ながらく紳士道の教育と純粋科学の研究に奉仕したイギリスの大学は, 産業 界との結びつきが弱い。政府白書『技術教育』（1956年）は大学と同レベルの工科力 レッジの創設を勧告したが，それ以前のイギリスの大学は応用科学の研究，産業技術 の担い手となる技術者の養成に注必ずしも積極的ではなかった。産業革命に続く時 代，大学は産業技術の開発に直接的な影響力をもたなかった（7)。中等教育および大 学以外の高等教育段階の技術教育の起源に重要な位置を占めた職工講習所 (メカニッ ク・インスティテュート）は，職業教育の制度化と独立して誕生した(8)。第一次世 界大戦後の座業抁張期に大学の化学科に濡要が殺到したことがある(9)。これは, 研 究中心の大学が職業教育機能を併せもち，これに払大する産業が人材の需要を大学に もとめた例である。産業の拡大に先行して, 大学の職業教育機能が充実していたとい う意昧で，この例は図1のCにあてはまる。しかし古典的大学が，すすみゆく産業革 命のインパクトに対応できなかった時代の两者の関係はDに相当する。

職業教育制度の整搹が，工業化を促進させたり，成熟した工業化社会の人材供給に

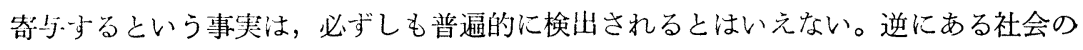
工業化が，職業教育制度を維持する条件になる場合もある。また両者間に影響関係が 十分に観察されないこともある。

\section{3 職業教育の尃門化と外的条件}

第二の䤅点は職業教育の専門化に関与るものである。学問分野の専門化，職種の 専旧化，さらには社会諸機能の専門分化が，職業教育にどのような影響をもたらして いるふが検討すべき課題となる。逆に職業教育の動向が，これら諸側面の必然的な帰 結であるかどうかが開われる。より具体的には，（a）社会変化は職業教育の専門化 にどのようなインパクトをおよぼすか，（b ）変化する需要に対応すべく専門化した 職業教育はどのような問題をかかえこむか，（c）専門化する職業教育は普通教育と の間にどんな関係を生みだすか，の三点にかかわる。

まず（a）は，さまざまな社会変化を独立変数とする職業教育の変質であるが，変 質の過侱は，既存部門の細分化と新規部門の出現という二つの方向を示す。独立変数 
として技術革新を例にとると理解しやすい。理工学部つ化学科の変遷は，産業技術の 高度化・細分化抢よび新技術の出現を反映している。工学部系統の化学科は, 早い時 期に化学工業学科または工業化学科に变化した。理学部系統では有機化学科と無機化 学科分化する。その過程は，一方では学問分野に沶ける専門分化に帰因すると同時 に, 他方では瀻維, 割業, 電気化学工業の発達と微妙にかかわる。これらは産業革命 後のより緩慢な变化である。より急激な变化を伴う，本格的な技術革新は，新技術・ 新産業の出現を促進させた。その過程およびその帰結として, 新しい職業教育分野が 生まれる。電子工学, 高分子化学, 制御工学, 情報工学などがそれに相当する。この ような既存学科の細分化と新規学科の誕生は, 大学なぞ高等教育機関だけでなく中等 教育段階の工業高校にもみられる。

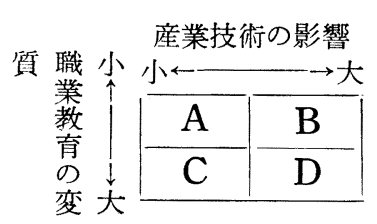

図 2 職業教育の変質の形態 技術革新の職業教育へのインパ クトは, 上に示した以上に複雑で ある。高校, 大学での学科名の変 更は技術革新の影響による場合と そうでない場合がある。学科名の 変更がなくても，実質的に教育内 容が変質する場合もある。両者の関係を概括的に図示すると, 四つのタイプに分けら れる(図 2 参照)。われわれは技術革新の直接的な影響を受けて，職業教育が大規模 に変質する状況（D）に注目しがちである。前に例示した工学部系統の新規学科のほ かに, 医学系 (医学, 衛生工学), 文科系（統計数理）にも職業教育の内容に変貿か 進行する。図 2 の他のタイプはそれぞれ特徵をもつ。産業技術からの影響を受けず， しか子職業教育に質的な变化を示さない $\mathrm{A}$ タイプには，伝統的な職業教育の内容と安 定的な産業技術が含まれる。外部からのインパクトに対して変化しないB タイプの職 業教育は，ある意味で自律的な機能をもっている。これには工学的ディバイスを䅡極 的に受容しない教員養成機関が含まれようか。そしてCタイプには，外部の变化を先 取する職業教育があげられる。

職業教育の変質は, 教育体系としての安定性と関係が深い。これは（b）の問題に 連なる。高度化した科学・技術を内在化することによって，職業教育が部分的に混乱 するとともに，内在化の過程で職業教育の目標と現実のギャップが生じるからであ る。つまり外部からのインパクトに対して職業教育が十分に対応しきれなくなり適応 障害をきたす場合,職業教育は内部的に混乱し，外部からの期待に対応できなくなる。 この傾向は理学, 工学, 医学, 農学の分野でもっとも顕著である。理学の一部起除く 分野は応用研究を基盤とする分野であるが,科学・技術の研究には,大別して基碟研究 - 応用研究・開発研究の三類型がある。応用研究に関する職業教育では, 常に基礎研 究, 開発研究の両者之接触する。

基楚研究において科学・技術のフロンティアがつぎつぎに開拓されると, 開発研究 


\section{職業教育の構造}

活動の組織は往々にしてたちおくれる。それと同時に開発研究活動の教育, 科学者・ 技術者の養成の組織編成にもラッグが生じる(10)。その結果，応用研究の成果を教育 する学部の学科編成は, フロンティフの変化に追随する形ですすめられる。ところが フロンティアの分野は絶えず交替し, 科学のライフ・サイクルは短縮化するため, こ の種の職業教育は将来を志向していたとしても過去を志向する結果となる。いわゆる “陳腐化” の現象である。大学など研究教育機関以外の場で, 基礎・応用・開発の才 ール・ラウンドの研究が蓄積されるシステムが形成されると，科学・技術者の養成を 担う職業教育のあり方が問われる。これは工学部だけでなく他の学部にも共通にあら われる状沉である。

（c）の職業教育と普通教育との関連は，いわゆる “総合技術教育” の理念のもと に職業教育の内容に関して検討される事項であるが，より広い視野からその両者の分 裂によって生じる緊張関係としてとらえることができる。文科の人間と理科の人間と の間に対話が成立しなくなった状況を手がかりにC・P・スノーは “二つの文化”の 断絶を指摘した(11)。これは経験的な観察を基礎にした一種の文明論であるが，科学・ 技術の極端な専門化の進行が，社会の均衡に脅威を与える側面を鋭くついている。職 業教育の専門化によって，科学・技術に関する部分的な知識のみに装備された人間は 社会の構造・制度の全体像をつかむことができない。その職業活動が果たす役割を， より広い社会的視野のもとで認識するために, 人文・社会科学の教育を強化する必要 性が生じる。

日本の新制大学発足の当初，理工学関係の職業教育に文科系の知識を補強すること に注意が払われた。やがて文科と理科の接近に関心が寄せられるにいたり，理工系の 学部に社会科学系の学科を增設する試みがなされる（社会工学）。あるいは理工系の 研究や教育を社会科学的にあつかうことが提唱される(ソフト・サイエンス)。これ

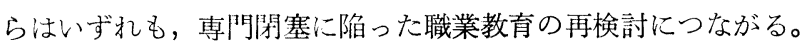

職業教育はこのように外社会との関連でその存在意義が問われる。社会変動の要素 のうち, 变化の激しい科学・技術とかかわりの深い分野の職業教育は, もっとも外部 からのインパクトを受けやすい。

\section{4 階層的地位決定における職業教育の機能}

第三の論点法, 職業教育の階層的性格に関する問題に焦点づけられる。とくに社会 の階㬝化に対して職業教育がぞのような機能を果たすかが中心的な課題となる。学校 教育の制度化に伴って社会階層が固定化し, 学校が階層的地位に人間を配分する装置 となる過程に注目与れば “学歴社会”の起源を遡及することができる。その過程は， 普通教育と職業教育の両面を含み, 上り広い分析視角を必要とする。学歴社会の形成 過程を跡ゔけるのは, 本稿の直接の目的ではない。しかし工業化との関連で, この形 成過程にも若干，触机なけ札ばならない。 
工場労働の組織を例儿とると，工業化の初期の段階では，生産活動従事者の大多数 注，未熟練労働者であった。労働の質も単純であり筋肉労働に大きく依存していた。 生産工程が複雑になるに伴って, 徒弟制度にみられるのとは異質な熟練が必要となる。 この熟練を習得するにあたって，特別の教育や訓練の機会を準備することが少なか ったため, 現場訓練 (on-the-job training) が主要な手段とされる。未熟練 $\rightarrow$ 半熟練 ＼cjkstart熟練の技能習得段階についての社会的な規準が確立しなかった日本では，現場労働 に初等義務段階以上の学校教育は必要とされなかった。早い時期に設立された帝国大 学はエリート養成を意図していたため，最上層に位置づけられる “技師”之底辺の労 働者の中間を占める人材を供給する職業教育機関の設立はおくれた。中等段階の工業 教育機関（徒弟学校，工業学校），大学ではないが高等段階の工業教育機関（高等工 業学校）の法制化をみたのは，離陸期を経た 19 世紀の末から 20 世紀の初頭である。 一方，産業組織が整備されるに従い，第二次産業の企業では，工員・職員を二分する 身分的階層分化が徐々に固定化される。高等工業学校出身者は当初から職員として雇 用されたが，中等段階の職業教育の出身者の処遇は不確定であった。しかしこれはほ えの初期の段階であり，大正期には職員層の供給源となる(12)。

ごく単純にいえば，分業の原則に対応した職業階層と職業教育に関与る学校段階が パラレルに照応したのではない。半熟練労働と専門化した職務の中間のある部分（テ クニシャンと熟練労働）を供給する職業教育機関を欠落したままであった。戦後の学 制改革, 最近の高学歴化の過程で, 戦前型の職業教育と階層との関係のある部分注消 隇したが他の部分はもちこされた。工員・職員分離の撤廃，旧制高等工業学校の大学 への昇格などは大きな変化である。高校卒・大学卒に新規採用を限定する企業が増大 したため, 高校卒ブルーカラーが一般化したのも学歴二階層の結合に変化をもたらし た。

しかし中等段階の職業教育出身者と高等段階のそれの間に明確な区分がなされ，階 層的地位の配分に学校段階差が反映されている。この状況は，高学歴化によって学校 段階による階層化がいかに稀薄化されても当分の間は崩壊しないであろう(13)。職業 教育の構造からみると, 中等段階と高等段階の間に連続性がそしい点（職業高校から 大学の専門コースへ入学が困難）と, 最終学歴のみが公認される点があげられる。こ のように日本の職業教育が硬直な構造であるのに対して, 渚外国で注成人に対する公 的な教育機会が相対的に大きい。サンドイッチによるディプロマ取得が可能なイギリ ス，マイスター制度が存続しているドイッでは，職業生活を通して習得される技術・ 技能が社会的に通用する資格として認定される。そして資格が寒少的な効用を発揮し， 社会的地位を決める指標ともなる。

職業教育だけが社会階層の形成要因として機能するわけではない。しかし社会的地 位序列のある部分の配分原理と職業教育の機能との間に注多様な関係があり，その関 係が国によって，時代によってどのように異なるか。また社会的地位の決定の規準が 
職業教育の構造

国によって異なる状況を知ることは，社会階層と職業教育の関係についての類型化に 有効である。

\section{5 周辺的部分の拡大}

公的な制度的背景をもつ職業教育機関が基礎的な教育を提供する。そしてそこ斑通 過することが社会的威信の獲得につながる。このように社会的に認定される職業教育 が主流であり，よりプラクティカルな職業能力の獲得・向上を可能にする機関は周辺 的にしか位置づけられていない。日本では学校教育法第 1 条に規定される学校（一条 校と呼ばれる）が正規なものであり，各種学校，職業訓練法に依拠する機関は正規の 学校として評価されない傾向にある。

ところが昨今，これら周辺的な職業教育機関の社会的役割が高まっている。これら は各職業の実務に直接かかわる知識，技術・技能を習得する機会を提供するところか ら，実務的教育の場であると評価されていたが，最近とみに重要視されるのはそれ以 上の効用が認められてきたからである。専修学校法の成立によって，公的性格を強め つつある各種学校には，文字通り各種の学校が含まれている(14)。そのうち本格的な 職業教育を実施しているものも少なくない。高校進学率の上昇も手伝って，これらが ポスト・セカンダリー・エデュケーションの性格を明らかにするに従い，高等教育レ ベルの教育内容を提供するようになる。その結果，時代に遅れがちな高等教育機関に 代替する機能を発掩する各種学校があらわれる。フロンティア技術に関する学校がそ の例である。

各種学校には，文部省以外の行政組織（厚生省，通産省など）の所管になる資格取 得に必要な学校も含まれる。これらは専門的な資格につながるため, 形としては各種 学校ではあっても, 実貿的には専門教育の諸条件を備えている。しかしそれでも正規 の学校に比べて䦌辺的な位置づけしか与えられていない例もある。看護婦, 臨床検査 技土，保母など福祉的な職業教育がその代表例である。これらは専門職業化を志何す る職業分野であるが，医師など“確立した專門職”の補助的な性格が残っているた め, 正規の職業教育に編成されない。最近,少数例として大学内に看護学部, 衛生学部 として独立したが，これらの職業の自律性が確立すれば，中核の分野に対する周辺的 性格は徐々に払拭されるかもしれない。職能団体の圧力団体的な面の強弱が，個々の 職業の専門性を高放，中核的な職業教育の位置づけを獲得する。大学工学部に対して， まだ周辺的な位置に沶かれている職業訓練校の場合も, 被訓練者の高学歴化と高齢化 を背景に，現在，一つの転換期を迎えている。“教育”と“訓練”の区分を除去与る 段階にきているこの分野は，䦌辺部分からの脱却を図っている(15)。

$※$

※

※

職業教育の構造法，職業的社会化のメカニズムに限定してもその外延は広範であ

り，多様な領域空包みこむ。そのため職業教育の内的事項を詳細に分析するためには 
別稿をまたなければならないが，本稿にとりいれた，“制度化”“専門化” “階層性” “周辺的部分” の検討により，関連する研究の位置づけが可能であり，今後の分析の 枠組の試論が展開される。

[注]

（1）職業的社会化の観点から職業教育の諸問題をあつかうと，職業観の形成，職業教 育の場の連続性・非連続性，職業能力開発の過程などのテーマがあげられる。これ らは必ずしもミクロな問題に限定されるわけではないが，本稿では割愛した。

（2）岩内亮一「日本の工業化における技術教育の役割」石戸谷哲夫編著『変動する社 会の教育』第一法規出版，1976年，245～265頁。

（3）教育経済学，教育投資論の基本的な観点にみられる。ただ最近は労働経済の側面 に関心が移っている。Stanley Lebergott, Manpower in Economic Growth, N. Y. McGraw-Hill, 1961. Sar A. Lavitan, Garth L. Mangum and Ray Marshall, Human Resources and Labor Market, N. Y. Harper and Row, 1972. Jacob Mincer, Schooling, Experience and Earning, N. Y. Columbia Univ. Press, 1974. などを参照のこと。

（4）旧工部大学校史料編纂会『旧工部大学校史料』1931年。

（5）河西瑳『工学博士藤岡市助君伝』1917年。

（6）岩内亮一「戦後日本の技術教育」『技術教育史』（梅根悟監修世界教育史大采 32）講談社，1978年，141１46頁。

(7) Sir Erick Ashby, Technology and the Academics, London Macmillan, 1958 , chap. I , 島田雄次郎訳『科学革命と大学』中央公論社, 1967。

(8) これについては, Thomas Kelly, George Birkbeck, Liverpool Univ. Press, 1957. C. Delisle Burns, A Short History of Birkbeck College, Univ. of London Press, 1924 に詳しい。

(9) P. W. Musgrave, Technical Change, the Labour Force and Education, Pergamon Press, 1967, pp. 144 145.

(10) 林雄二郎・山田圭一編『科学のライフサイクル』中央公論社，1975年，第 5 章。

(11) C. P. Snow, The Two Cultures : and A Second Look, cambridge, Cambridge at the Univ. Press, 1964 松井巻之助訳『二つの文化と科学革命败すず書房, 1967。

(12) 詳細は『産訓練業百年史』日本産業訓練協会，1971年を参照のこと。

(13) 生しろ高等教育内の格差 (短大, 高専, 大学, 大学院, さらには設置者別の格差) が重要であるが，ここでは省略しなければならない。

(14) 各種学校については, 本学会の倉内史郎, 関口義両氏分笑態の調查報告, 論評を 重ねている。詳細はこれらに明らかである。

(15) 山田雄一「職業訓練政策」『季刊 労働法』別卷第 2 号，1978年，179～188页。 
chief of family. In his place, mother performes multiple roles, those of socialization of children and emotional cathexis. She defines the relation between school and family. Children and adolescents tend to be separated from their local community.

Thus, occupational activities, which define the way of their lives, play the central role in family. School becomes to be subject to the occupational system. The integrative function of the community has been weakened. Our societal community tends to be organized with the occupational system in the center. It is the family that adapts its members to these changing situation. Therefore, it seems necessary to do more specific study of the relations among occupation, school and family.

\title{
Educational Opportunity and Ability for Self-Direction
}

\author{
Takahiro Kihara \\ (Okayama University)
}

The educational opportunity is actually open to all social classes in modern Japan. 94\%of Japanese boys and girls go to senior high schools and $34 \%$ of them go on to the institutions of higher education. But today educational institutions become a selective agency and do not always perform educational functions. This paper deals with what kind of impact educational institutions give upon the Japanese youth.

\section{Structure of Occupational Education}

\author{
Ryoichi Iwauchi \\ (Meiji University)
}

An assertion, that a well-organized occupational education manifests its 
function for the producing of industrial manpower for take-off in developing societies as well as for the supplying of enough lots of high quality of various types of manpower in industrial societies, has been accepted by policy-makers and academicus.

For the improvement of this educational system, it is lively admitted to provide policy-making of the fundamental elements of the occupational education with financial subsidies, teaching and research staff, physical equipments and so forth.

However, the general assertion of this type to stress the importance of institutionalized occupational education for industrialization of a society seems to be criticized and refined. This paper attempts to prepare a theoretical framework of occupational education with particular emphasis on social change. For this purpose, four points of view are discussed. (1) A proposition that institutionalization of the system of occupational education of public sector promotes the social development has to be altered and re-examined by a detailed discussion through an analytical scheme. (2) Professionalizations of social elements affect the role and character of occupational education, and simultaneously occupational education is oriented to professional diversity. Consequently, the impact of professionalization involving the front of technical innovation shows various confusions in the organization of occupational education. (3) The system of occupational education relates with the social stratification. Output of this educational system influences the configuration and formation of social class, and conversely it is affected by a principle of distribution of social status, as well as a principle of job endorsement. (4) Peripheral part of occupational education is increasing its function with the demand of industrial sector. This trend is the result of rapid social change, access of industrial training to occupational education. 